\title{
Incapacitated decision making power, over emphasized obedience and its exclusionary effects on children
}

Asad Ullah

The University of Agriculture, Peshawar

Mussawar Shah

The University of Agriculture, Peshawar

\begin{abstract}
The objective of this paper is limited to determine the exclusionary effects of poor decisionmaking power of children and variation to their effects among children based on their gender, religion, family background and subjective poverty. A total of 500 children (12-18 years) were selected by systematic sampling technique from seven shopping streets and seven high schools of the District Peshawar, and interviewed. Likert scale was used as a measurement tool. Association of variables was ascertained by using Chi-square test and Kendall's Tau-b tests, at bivariate and multivariate level. At bivariate level relationship of social exclusion was significant and negative with feeling one's self influential in molding family level decision, having membership of any organization, liberty in choice of sport, liberty in choice of dress/shoes and people listen to child's views. At multivariate level, the exclusionary effects of poor decision making power among children varied on the basis of their gender (male and female) and religious affiliations (Muslims and non-Muslims). Contrariwise, result of groups based on sufficiency of family income indicated a nonspurious relationship between power of making decision in children and their social exclusion. Likewise, result of groups based on joint and nuclear family affiliation indicated a non-spurious relationship between power of making decision in children and their social exclusion; conversely, single parent family group had a spurious relationship with above two groups. Ensuring child's constructive social participation at family and community level activities, reintegration of family role in child's physical, social and psychological care and socialization, and overcoming gender and religion based disparities in the society were some of the policy recommendations in light of the study.
\end{abstract}

Keywords: social exclusion, decision making power, children, gender, family income, religion, family Type

Poverty is a major component in moulding human life. It, however, is mostly concerned with economic aspects of disadvantage, and mostly applies static set of indicators like income, expenditures etc. (Department of Social Security, 1999). The concept of social exclusion helps to understand the dynamic process of deprivation that causes the conditions of disadvantage in broader social and economic context (Commins, 2004).

Corresponding author: Asad Ullah (asadpsh@aup.edu.pk) 
Social exclusion is a condition, when a number of people suffer from a combination of linked problems like unemployment, low skills, low income, poor housing, high crime environment, poor health and family breakdown with other combined factors to trap individuals/groups in a spiral of disadvantage (SEU, 1997; and DSS, 1999). It is associated to the process of shutting out the individuals/groups from one of social, economic, political and cultural system, necessary for integrating individuals in a society. This Exclusion could be due to individual's physical or mental inabilities or due to other socio-economic reasons like income, gender, race, ethnicity etc. (Walker and Walker, 1997; and Burchardt et al., 2002).

The phenomena of social exclusion could easily be explained through two major facets i.e. denial to participate (as external) and inability to participate (as internal). Moreover, a society can assess its social unity and individuals' prosperity in the context of social exclusion. (Barnes et al., 2006).

The aggravated form of social exclusion is conspicuous in children (Marsh et al., 1999) therefore; children have been shown as one of the most demanding research agent of Social exclusion (Levitas et al., 2007). Disparities of ethnicity, dismemberment of neighbourhood, inequalities in gender, physical disabilities, broken family, inferior family occupation and family income are major indicating factors leading towards social exclusion in children (Better Regulation Task Force, 2004; and Levitas et al., 2007). Therefore several international laws and conventions like convention on the right of the child (1989) has asserted for provision of distinctive assistance and care to children because of their mental and physical immaturity.

Various agents of child socialization, like family and friends, have a significant role in refining children's decision-making abilities and their subsequent inclusion in main stream society. These agents train children in making appropriate choices in different situations. Role of social relations with family friends and neighbours is eminent in feeling responsible role, useful participation in social activities, and gaining respect. Importance of family for training their children to adopt proper and gender non-discriminatory techniques for engaging children in the societal activities is ever increasing (SEU, 2006). Sutton et al. (2007) pointed out low participation in organized social activities in children, especially from poor economic background, as a source of social exclusion in them. However, strong relationship with family and friends shield children against negative effects of poverty, depression, pessimism and stigma of poverty (Backett-Milburn et al., 2003).

Children and young people have the right to express their ideas and be actively involved in building their futures and to make cultural progress (Berti, 2003). Children, overwhelmingly, are found reporting their poverty in context of their social relations, than their access to material resources. The analysis of the variable makes it clear that participation in common social activities provides a strong base to children in participation in group activities like prayers, discussions, civic activities and club membership that in its turn reduces the chances of social exclusion in such children (Backett-Milburn et al., 2003).

The state of Pakistan in context of deprivations amongst children is touching alarming level, chiefly due to economic inequality. The obvious results are high mortality rate $(27 \%)$ and with child mortality $19 \%$ high than nations of similar economic position, $67 \%$ higher death rate in girls than boys within age bracket of 1-4 years. The school enrolments also depict a gender based discriminatory environment with some visible barriers to female education. Social class is recognized as a major line of fragmentation within the social structure in Pakistan due to the prevailing feudalistic milieu in most part of the country. Other dividing factors include religion, class, caste and ethnicity. Situational analyses show that most of the benefits are only received by the upper class and the poor are forced to be at the back (Silver, 1998; SPARC, 2011; and Australian Government, 2009). 
Futuristic vision to induct capable workforce into society demands for understanding children's problems in their voices. The research studies are criticized for their information based on proxy responses. To overcome the problem, the research needs to be conducted with children rather on children, where children are on foreground and their active participation acknowledged. There is a mounting need to have objective view, as how the children see their societal networks and supports around themselves, and how they want to be involved (Castillejo, 2012; and Christensen and James, 2000).

Keeping into account the reliability of the primary data and the afore mentioned scholastics conclusions this study was designed with the sole purpose of exploring the decision making power dimensions of the children based on the real data from the respondents in the study.

\section{Method}

The present study was carried out in Peshawar District of Khyber Pakhtunkhwa provincePakistan to determine the association between social exclusion and power of making decision. The research study was a "Cross Sectional" study based on its time horizon (Babie, 1989).

The study area comprised of 461 registered high schools (BISE Peshawar, 2011) and fifteen different shopping streets (Bazars) spread over the whole District Peshawar (Bureau of Statistics, 1998). Sekaran (2003) recommended a sample size of 500 respondents for a larger population, like one in this study were Children aged 12-18 years, enrolled in high schools and/or involved in labour at various shops/workshops were deemed to be in a position to better understand and respond to first-hand information. For selection of respondents the following two-stage probability sampling procedure was adopted;

At first a total of seven (7) schools and seven (7) bazars were randomly selected from the available list of schools and Bazars. For preparation of sampling frame, a list of enrolled students in selected schools, as per study criteria, was obtained from school administration, whereas, a pilot study was conducted to enlist the children working in Bazars/workshops. Help of members of shopkeepers/workshops associations was solicited for conducting the pilot survey at bazars and subsequently for main data collection over there. To ascertain a firm grip of the researcher and ensure better quality of research through reliable data regarding study variables, a systematic sampling procedure was adopted at second stage (Cooper and Pamela, 2010). A systematic sampling is advantageous over rest of sampling techniques in its simplicity and flexibility. It also ensures proportional allocation of respondents to all strata (schools and markets). It was simple for researcher to instruct surveyor to choose kth student from a class, or child/children working in kth shop/workshop for interview. The sampling technique helped in avoiding the need for drawing a long personal file for drawing a sample from it.

For drawing systematic sample, the following procedure was adopted:

1. Seven schools and seven bazars were randomly selected from available list of schools and bazars.

2. Elements of population from each stratum (school and shopping street) were identified and listed through pilot survey/secondary data review.

3. The required sample size was proportionally allocated to each stratum (school/bazar)

4. Skip interval $(k)$ was identified for each stratum by using following formula

5. Random start was identified

$$
\mathrm{k}=\text { Skip interval }=\frac{\text { population size }}{\text { sample size }}
$$

6. Sample was drawn by using every kth entry. 
Following the above procedure, a total of 300 respondents were selected from shopping streets and 200 from schools including government semi government and private (nongovernment) schools.

The conceptual framework was designed with a dependent variables (Social Exclusion in children) an independent variable (power of making decisions, Table-1) and four background variables (gender, religion, family type and sufficiency of family income).

Table 1: Conceptual framework

\begin{tabular}{|l|l|l|}
\hline Background variables & Independent Variables & Dependent Variables \\
\hline Gender & Power of making decisions & Social Exclusion in children \\
Religion & & \\
Sumily type & & \\
\hline
\end{tabular}

Keeping in view the presumed low level of understanding of children than adults, the interview schedule was constructed on dichotomous form of simple attitude scale (Likert scale), a sub category of rating scale. The Interview Schedule was translated into local vernacular (Urdu/Pushto), and pre-tested with a small group of 25 children from school and bazars (Kothari, 2004). The inconsistencies and ambiguities in the interview schedule were corrected before actual data collection to ascertain reliability of data and achievement of study objectives. The data was collected by a team of investigators, hired for the said purpose and lead by the researcher himself. The investigators were properly trained prior to data collection. Prior consent of Principals/Headmasters was solicited for interviewing students at their schools. Similarly, help of shopkeepers' association officials were asked for allowing interviewing children at work. APA norms for research were followed for interviewing children and handling data. The children, prior to interview, were briefed about the purpose of study and significance of the information gathered from them. The data was collected from children willing to participate in the process, in isolation from others and after rapport had been established. It took almost three months to complete data collection process.

Keeping in view the relativity, agency and dynamics components of the process of social exclusion, a group of indicators of social exclusion in children was identified from the existing literature, expert views and personal experience of researcher. The indicators were vetted by a panel of experts (members of departmental board of studies). Based on the recommendations of experts, measurement of social exclusion was based on nine attributes (indicators) namely non-participation in social activities out of fear of failure to meet people's expectations, feeling of disrespect from others, feeling of representation from low caste, poverty, deprivation, child labor, poor aspirations for future life, left out by people due to unwanted personality and poor access to contacts. The responses were obtained on a dichotomous scale such that "No" (inclusion on particular attribute) was given the value of 0 and "Yes" (Social exclusion) was given the value of 1 . The attributes were indexed for squeezing the data and getting a summary result. Two groups i.e. "socially excluded" and "socially included" were identifies based on data analysis. A child was considered as socially excluded if he was excluded on five or more attributes of social exclusion.

Measurement of "power of decision making" as causative factors of social exclusion was based on attitudinal statements (eight items) pooled from available literature and vetted by departmental board of studies members. All the attributes so developed were floated to the respondents for collecting information. Moreover the background variables were measure on a scale as Gender (1 item), Sufficiency of Family Income (1 item) and Religious Affiliation (1 item). The responses for all questions were obtained on a dichotomous scale. It is pertinent to mention that the question on perception of poverty was introduced to measure subjective 
poverty (perceiving one's self/family as rich or poor irrespective of the fact that basic needs are met or not). A child was considered as deprived on a particular scale of variable measurement (e.g. poor decision-making power) if he/she had negative attitudinal responses towards half or more factors in that scale (Nachmias 1992).

One of the standards in the social sciences research is indexation, especially for attitude statements. Indexation involves at least two items for measurement of a single variable. Thus, index construction is combining two or more items in a variable (Nachmias, 1992). Cronbach's alpha test was used to ascertain the internal consistency of the elements that constitute the index. An Alpha coefficient value of 0.7 indicates that items in the scale are tightly connected and are appropriate for indexation (Nachmias, 1992). Value of Cronbach's alpha coefficient for both independent and dependent variables lied between 0.7 and 0.9 , therefore, data was found internally consistent and indexed for multivariate analysis.

The data was analysed by using uni-variate, bi-variate and multi-variate techniques of data analysis. At uni-variate level frequencies and percentages were worked out, whereas, at bivariate level dependent variable was indexed and cross tabbed with attitudinal statements of independent variable. Moreover, at multi-variate level, both independent and dependent variables were indexed and cross tabulated, while controlling gender, religion, family type and sufficiency of family income of the respondents, to test the spuriousness or nonspuriousness of their relationship. Reliability analyses were also carried out and the Cronbach's alpha test coefficient was found more than 0.7 for both independent and dependent variables. Chi-square test was used to test the association between the two variables as devised by (Tai, 1978).

Wherever, the assumption of chi-square test was violated in the data, Fisher Exact Test was used instead of simple Chi-square. The relationship developed by the Fisher is given in equation below (Baily, 1982);

Furthermore, Kendall's Tau-b was used for calculating direction of association for contingency tables. Kendall's tau-b is most appropriate measure of association for two levels response data, where marginal distribution is uneven in $2 \times 2$ tables with many ties (Nachmias, 1992).

\section{Results}

\section{Power of making decisions}

Any approach studying the social exclusion in the children could markedly be classified into four main dimensions i.e. the right to survival, development, protection and participation. Decision making power enable individuals to participate in all micro and macro level activities of life and perform positively in smooth functioning of the social system. Perception regarding this important aspect of the study was ascertained by devising some of the attributes, which could truly reflect the real essence of the study at hand with all its manifestations.

Majority of respondents (86\%, Table 2 ) had no affiliation to any political parties and $76.6 \%$ did not participate in any political rallies. It could be deduced from the above inferences that the respondents had a particular age level below 18 years. Although this age bracket serves as a transition of making one self-capable while entering into practical life yet these children had little freedom to participate in any political activities due to high level of restrictions from their families. Political affiliation and participation in political activities is considered as a family level decision made by elders of that family. The children, as observers, learn about political participation of their elders and the reasons for making such decisions. Once an individual enter into the job market he get access to any political activity. A restriction in 
child's decision-making processes is considered as conformity to the cultural values. However, it costs children with low anticipative vision, poor interpersonal relationship, sense of subordinate position and poor leadership traits (White et al., 2002; and Bradshaw et al., 2004).

Respondent's negated their participation in family level decisions $(70.8 \%)$ and, if participated, had no influence on family level decisions (71.6\%) respectively. Children being subordinate in hierarchy in family level are seldom consulted in decision making pertaining to family issues. The whole reason of denial could be their economic inabilities to work as an economic unit or immaturity to visualize the problem. The children generally are asked to leave the place where elders are discussing family issues, or they are supposed to remain silent in these meetings. Roker (1998) had also suggested, based on his studies, a key role is performed by those children who had a source of payment either from the government in the form of grants or paid work.

Furthermore, 94\% respondents were non-members to any organization, $53 \%$ had liberty to choose and participate in sports, $62 \%$ had liberty in choosing dresses and shoes however, $78.4 \%$ were ignored by others in listening to them respectively. The above data clearly indicated a socially restricted environment prevailing in the study area with little choice left for children to have the right to participate in any sports activities along with a choice in selection of shoes and dresses etc. It could either be due to the low economic position of respondent's families to pay membership fee of clubs, scarcity of clubs for youth activities or cultural obligation on part of children to keep silence and sacrifice wishes in the name of obedience. Kid's status (2007) had revealed a positive correlation amongst the poverty, denial to sports activities, non-provision of freedom in the expression and role performance in the society with social exclusion.

Table 2: Frequency distribution and proportion of respondents showing variable responses to their power of making decisions

\begin{tabular}{|l|c|c|c|}
\hline Attribute & No & Yes & Total \\
\hline You have affiliation to any political party & $429(85.8)$ & $71(14.2)$ & $500(100)$ \\
\hline You participate in political rallies & $383(76.6)$ & $117(23.4)$ & $500(100)$ \\
\hline $\begin{array}{l}\text { You are allowed to participate in decision making at } \\
\text { family }\end{array}$ & $354(70.8)$ & $146(29.2)$ & $500(100)$ \\
\hline You feel you can influence family level decisions & $358(71.6)$ & $142(28.4)$ & $500(100)$ \\
\hline You are member to any local/national organization & $470(94.0)$ & $30(6.0)$ & $500(100)$ \\
\hline $\begin{array}{l}\text { You are at liberty to choose and participating in any } \\
\text { sport }\end{array}$ & $265(53.0)$ & $235(47.0)$ & $500(100)$ \\
\hline $\begin{array}{l}\text { You are at liberty in choosing your dresses and } \\
\text { shoes }\end{array}$ & $310(62.0)$ & $190(38.0)$ & $500(100)$ \\
\hline $\begin{array}{l}\text { People listen to you and give importance to your } \\
\text { views }\end{array}$ & $392(78.4)$ & $108(21.6)$ & $500(100)$ \\
\hline
\end{tabular}

Values in table present frequency while values in parenthesis represent percentage proportion of respondents

Association between power of making decisions and social exclusion in children Multidimensionality of social exclusion makes it a complex phenomenon, distinct from poverty. Income deprivation is main feature of social exclusion like in poverty; however, social exclusion involves additional factors like lack or denial of goods, services, rights, power and participation. Comprehensive approaches on wellbeing of children stress on children's socio-economic, civil, cultural and political rights. One of the features of wellbeing approach in children is based on practical efforts for their empowerment in decision-making process. This empowerment may range from making choices for their personal daily needs to involvement in family and community level decisions. Findings regarding relationship 
between child's power of making decision and social exclusion in children are given in Table 4 and explained as follows.

For those who were socially excluded $11.4 \%$ had political party affiliations, compared to $16.4 \%$ of those that were socially included. Affiliation to any political party was nonsignificant and negatively related $\left(T^{b}=-0.072\right)$ with social exclusion. Socially included children had a slight advantage over excluded children in terms of affiliation to political parties. Political parties as an organization in themselves possess different programs of growth and wellbeing for the local population. Although informal, yet these organizations arrange different types of meetings for portraying their manifesto and extending messages to the participants for making it public. This kind of activities provides a frequent rate of interaction to the participants. However, these activities, as indicated by the result of the study, were confined to adults above 18 years of age and little option of participation for excluded children could be assumed based on non-registered voter. In addition, involvement of children in other chores based on livelihood attainment and education restricted their access to political parties to participate and groom in their lifestyle. Moreover, organizing children for ensuring their rights was non-existing in the study area. Recognition to political, cultural, social and civil rights is highlighted in the UNICEF charter for children. Moreover, their rights to participate in political parties just to protect them against discrimination have been augmented through the convention on the child rights. All these have been envisaged in article-7 and 8 that emphasizes for acquiring a name and nationality soon after getting birth. Moreover, article-2 and 3 of the same convention emphasizes over children with minority background have the right to participate in their own culture with allied activities (UNICEF, 2011; and The convention on the Rights of the Child, 1989).

Table 3: Association between power of making decisions and social exclusion in children

\begin{tabular}{|c|c|c|c|c|c|}
\hline \multirow[t]{2}{*}{ Power of Making Decisions } & \multirow[t]{2}{*}{ Attitude } & \multicolumn{3}{|c|}{ Social Exclusion } & \multirow{2}{*}{$\begin{array}{l}\text { Statistics } \\
\chi^{2} \\
\text { (P-Value) } \\
\mathbf{T}^{\mathbf{b}}\end{array}$} \\
\hline & & $\begin{array}{l}\text { Socially } \\
\text { Included }\end{array}$ & $\begin{array}{l}\text { Socially } \\
\text { Excluded }\end{array}$ & Total & \\
\hline \multirow[t]{2}{*}{$\begin{array}{l}\text { You have affiliation to any political } \\
\text { party }\end{array}$} & No & $\begin{array}{c}234 \\
(83.6)\end{array}$ & $\begin{array}{c}195 \\
(88.6)\end{array}$ & $\begin{array}{c}429 \\
(85.8)\end{array}$ & \multirow{2}{*}{$\begin{array}{l}\chi^{2}=2.59 \\
(0.107) \\
T^{b}= \\
0.072\end{array}$} \\
\hline & Yes & $46(16.4)$ & $\begin{array}{c}25 \\
(11.4)\end{array}$ & 71 (14.2) & \\
\hline \multirow[t]{2}{*}{ You participate in political rallies } & No & $\begin{array}{c}216 \\
(77.1)\end{array}$ & $\begin{array}{c}167 \\
(75.9)\end{array}$ & $\begin{array}{c}383 \\
(76.6) \\
\end{array}$ & \multirow{2}{*}{$\begin{array}{l}\chi^{2}=0.105 \\
(0.746) \\
T^{D}=0.014\end{array}$} \\
\hline & Yes & $64(22.9)$ & $\begin{array}{c}53 \\
(24.1)\end{array}$ & $\begin{array}{c}117 \\
(23.4)\end{array}$ & \\
\hline \multirow[t]{2}{*}{$\begin{array}{l}\text { You are allowed to participate in } \\
\text { decision making at family }\end{array}$} & No & $\begin{array}{c}199 \\
(71.1)\end{array}$ & $\begin{array}{c}155 \\
(70.5)\end{array}$ & $\begin{array}{c}354 \\
(70.8) \\
\end{array}$ & \multirow{2}{*}{$\begin{array}{l}\chi^{2}=0.023 \\
(0.880) \\
T^{b}=0.007\end{array}$} \\
\hline & Yes & $81(28.9)$ & $\begin{array}{c}65 \\
(29.5)\end{array}$ & $\begin{array}{c}146 \\
(29.2)\end{array}$ & \\
\hline \multirow[t]{2}{*}{$\begin{array}{l}\text { You feel you can influence family } \\
\text { level decisions }\end{array}$} & No & $182(65)$ & $176(80)$ & $\begin{array}{c}358 \\
(71.6)\end{array}$ & \multirow{2}{*}{$\begin{array}{l}\chi^{2}=13.63 \\
(0.000) \\
T^{b}=- \\
0.165\end{array}$} \\
\hline & Yes & $98(35)$ & $44(20)$ & $\begin{array}{c}142 \\
(28.4)\end{array}$ & \\
\hline \multirow[t]{2}{*}{$\begin{array}{l}\text { You are member to any local/national } \\
\text { organization }\end{array}$} & No & $\begin{array}{c}255 \\
(91.1)\end{array}$ & $\begin{array}{c}215 \\
(97.7)\end{array}$ & $470(94)$ & \multirow{2}{*}{$\begin{array}{l}\chi^{2}=9.67 \\
(0.002) \\
T^{b}=- \\
0.139\end{array}$} \\
\hline & Yes & $25(8.9)$ & $5(2.3)$ & $30(6)$ & \\
\hline \multirow[t]{2}{*}{$\begin{array}{l}\text { You are at liberty to choose and } \\
\text { participate in any sport }\end{array}$} & No & $\begin{array}{c}120 \\
(42.9)\end{array}$ & $\begin{array}{c}145 \\
(65.9)\end{array}$ & $265(53)$ & \multirow{2}{*}{$\begin{array}{l}\chi^{2}=26.28 \\
(0.000) \\
T^{b}=-\end{array}$} \\
\hline & Yes & 160 & 75 & $235(47)$ & \\
\hline
\end{tabular}




\begin{tabular}{|c|l|c|c|c|l|}
\hline & & $(57.1)$ & $(34.1)$ & & 0.229 \\
\hline $\begin{array}{l}\text { You are at liberty in choosing your } \\
\text { dresses and shoes }\end{array}$ & No & $\begin{array}{c}120 \\
(42.9)\end{array}$ & $\begin{array}{c}190 \\
(86.4)\end{array}$ & $310(62)$ & $\begin{array}{l}\chi^{2}=98.97 \\
(0.000)\end{array}$ \\
\cline { 2 - 6 } & Yes & $\begin{array}{c}160 \\
(57.1)\end{array}$ & $\begin{array}{c}30 \\
(13.6)\end{array}$ & $190(38)$ & $\begin{array}{l}T^{b}=- \\
0.445\end{array}$ \\
\hline $\begin{array}{l}\text { People listen to you and give } \\
\text { importance to your views }\end{array}$ & No & $\begin{array}{c}185 \\
(66.1)\end{array}$ & $\begin{array}{c}207 \\
(94.1)\end{array}$ & $\begin{array}{c}392 \\
(78.9)\end{array}$ & $\begin{array}{l}\chi^{2}=57.11 \\
(0.000)\end{array}$ \\
\cline { 2 - 6 } & Yes & $95(33.9)$ & $13(5.9)$ & $\begin{array}{c}108 \\
(21.6)\end{array}$ & $\begin{array}{l}T^{b}= \\
0.338\end{array}$ \\
\hline Column wise total & & $\begin{array}{c}\mathbf{2 8 0} \\
\mathbf{( 1 0 0 )}\end{array}$ & $\begin{array}{c}\mathbf{2 2 0} \\
\mathbf{( 1 0 0 )}\end{array}$ & $\mathbf{5 0 0 ( \mathbf { 1 0 0 } )}$ & \\
\hline
\end{tabular}

Values in table present frequency while values in parenthesis represent percentage proportion of respondents

The result further indicated that $24.1 \%$ of socially excluded children participated in political rallies, compared to $22.9 \%$ of the socially included. Participation in political rallies was found non-significant and positive $\left(\mathrm{T}^{\mathrm{b}}=0.014\right)$ with social exclusion. Local culture was highly enriched with encouragement for participation from all segments of society in different kind of rallies. Some were religious and some of these were political and even communal in nature. These rallies provided opportunity to the excluded minorities to participate. However, such rallies were not frequent, rather situational and spontaneous in nature. Political disengagements due either to non-registration in political parties or seldom participation in their rallies were one of the dimensional factors of social exclusion. Moreover, age based restrictions reducing involvement in political activities of the youth as compared to old age people. Other sociological studies also indicated no/low likelihood of youngsters' involvement in political activities (Levitas, 2006; and Fahmy, 2006).

Likewise, $29.5 \%$ of socially excluded children were allowed to participate in decision making at family level, compared to $28.9 \%$ of the socially included. Participation in decision making in family had a non-significant but mild positive $\left(\mathrm{T}^{\mathrm{b}}=0.007\right)$ association with social exclusion. Both socially included and excluded groups had almost similar proportion of representation in terms of participation in decision-making activities at family level, therefore none of the group had a clear advantage over other group in this regard. Age is a determining factor in indicating towards the level of participation of an individual in different paths of life. Being patrilineal and structural, the local family setup has designed a methodology where decisions pertaining to family matters had been declared as the only domain of the elders. Children with lesser age were assumed inexperienced, lacking wisdom and volatile in personality. However, chances of participation could not be ruled out but termed as dismal in proportion. Saunders (2007) concluded that the causes of exclusion are the results of low educational background, family income, poverty, restricted access to resources, and extreme state of deprivations. However, there is a link between social exclusion and social discrimination characterized by non-participation in decision making on civil, social and cultural aspects of life (UN, 1948).

The result showed that $20 \%$ of socially excluded children felt that they could influence family level decisions, compared to $35 \%$ of the socially included. A highly significant $(p=0.000)$ but negative $\left(T^{b}=-0.165\right)$ association was detected between feeling influential in molding family level decision with social exclusion. It could be attributed to the firm stand of the respondents on their relative efficiencies for giving positive inputs in the decision at family level. However, they were found restricted with almost rare chances of participation. Cultural perspectives were highly vivid, where children were not taken as wise to be at par with the elders pertaining to their inputs in the decision. Lack of exposure to experience and low level of participation in the family affairs and outside could be some of the reasons associated to lack of necessary skill and revitalizing the hopes to provide strength to their own stand on 
different issues were one of the dilemmas with the socially excluded persons. Moreover, cultural progress is impossible until and unless children are judged beyond the curtain of cultural perspectives in the greater orbit, as they are the just successors of their elders in the family. Besides, social exclusion and social capital both are indispensable. Strengthening social capital means more and more participation and thus reducing the distance of social exclusion (Berti, 2003; Hoffmann-Extein et al., 2008; and SEU, 2006).

From the children who were socially excluded $2.3 \%$ were a member of an organization, compared to $8.9 \%$ of the socially included. Membership of any local or national organization was found significant with social exclusion $(p=0.002)$ but negative in direction $\left(T^{b}=-0.139\right)$. Membership of an organization reduced likelihood of social exclusion among children. However, children had rare opportunity to get membership of any organization. Moreover, for those that were socially excluded $34.1 \%$ had liberty in choice of participation in sports activities, compared to $57.1 \%$ of those that were socially included. Freedom to choose and participate with liberty in any sport was found highly significant but negative in direction $\left(p=0.000\right.$; and $\left.T^{b}=-0.229\right)$. Different games including both national level and local were in abundance in the area. However, chances of playing a game of choice were restricted to these excluded persons either due to extreme poverty, having little time to participate rather going out for earning, or due to culturally segregated background based on ethnic and minority considerations. Social relationship network is one of the indexes for evaluation of level of participation for all age and ethnic groups. Poor social relations among neglected segments of society (gender, ethnicity and age group) reduce chances to participate in decision-making pertaining to education and sports, especially in low-income families. This was further augmented in a study in Australia where choice of participation in sports was restricted for poor and minority classes (Kids Status, 2007; and Taylor and Fraser, 2003).

Furthermore, $13.6 \%$ of socially excluded were at liberty in choosing dress/shoes, compared to $57.1 \%$ of the socially included. Likewise, for those who were socially excluded $5.9 \%$ were listened to and given importance, compared to $33.9 \%$ of the socially included. Child group liberty in choosing dress and shoes were found highly significant $(p=0.000)$ along with people listen to you and give importance to your views was highly significant $(p=0.000)$ but negative in direction $(\mathrm{Tb}=-0.445$; and $\mathrm{Tb}=-0.338)$ respectively with social exclusion. It is imperative that giving chances of freedom for dress and shoes, choice and listening to excluded persons with respect and importance could lead to the mitigation of social exclusion. However, due to cultural non-provision, views and suggestions of children were rarely listened and given importance. Thus, it could be extrapolated from the results that children below age 18 years had little level of permission to freedom of expression regarding the choice selection in their lives, which in turn enhanced the probability for them to face with social exclusion. Feeny and Boyden (2004) and Sutton et al. (2007) have concluded that social exclusion is directly related to low participation of the deprived children with limited access to selection of clothes for summer and winter along with shoes. Similarly, participation in social activities by the children with low-income background was strongly related to their social exclusion. Moreover, families with low parent income had significant relationship with high profile of worries for families regarding the life reconciliation as per wants and desires in the social milieu. Thus, a clearly articulated impact is associated between social exclusion and poverty in children. Moreover, teenagers who experienced no access to choice of clothes amongst their peers had a visible signs of inferiority and social isolation (Ashworth et al., 1994a and b; and Shropshire and Middleton, 1999).

\section{Associations between power of making decision and social exclusion in children} (controlling gender, religion, family type and sufficiency of family income of the respondents) For those male respondents who were socially excluded $95.6 \%$ had weak decision-making abilities, compared to $80 \%$ of the socially included. Likewise, for those female respondents that were socially excluded, $96.7 \%$ had weak decision-making abilities, compared to $93.3 \%$ 
of the socially included. Weak social relations with neighbours were marginally disadvantageous to females than males, depicted from above percentage distribution. A negative relationship $\left(T^{b}=-0.220\right)$ was found between power of making decision in male and their social exclusion (Table 5). The relationship between these variables was also highly significant $(\mathrm{p}=0.000)$. Contrary to above group, in female this relationship was non-significant $(p=0.469)$ and negative $\left(T^{b}=-0.076\right)$. The values of level of significance of the entire table show a highly significant $(\mathrm{p}=0.000)$ and negative $\left(\mathrm{T}^{\mathrm{b}}=-0.220\right)$ association between power of making decision and social exclusion for both genders. The variation in Kendall's Tau-b values for male and female indicated that gender as control variable explain variation in relationship between power of making decision in children and their social exclusion at bivariate level. Therefore, males had an edge over the females regarding decision making power while encountering social exclusion, whereas female with weak decision-making power were slightly more prone to social exclusion. This could be attributed to the local cultural milieu where males had great liberty in decision making compared to females. Confidence derived out of liberty enabled the youngsters with more choice and freedom as indicated by Sutton et al. (2007) that participation in social activities enhances the decision power amongst males. Moreover, group activities dictates towards four possible options like right to survival, right to development, access to information and right to participation. All these four dimensions are the strong indicators of social participation (Whites et al. 2002). Moreover, cultural progress is also dependent on maximum participation from youngsters.

In addition, by controlling religious affiliation of respondents, for those Muslim respondents who were socially excluded, $97.2 \%$ had weak decision-making abilities, compared to $84.9 \%$ of the socially included. Likewise, for those non-Muslim respondents who were socially excluded, $50 \%$ had weak decision-making abilities, compared to $51.7 \%$ of the socially included. A negative relationship $\left(\mathrm{T}^{\mathrm{b}}=-0.210\right)$ was found between power of making decision in Muslim respondents and their social exclusion (Table 5). The relationship between these variables was also highly significant $(p=0.000)$. Contrary to above group, in non-Muslim respondents this relationship was positive $\left(T^{\mathrm{b}}=0.013\right)$ but non-significant $(p=0.939)$. The values of level of significance of the entire table show a highly significant $(p=0.000)$ and negative $\left(\mathrm{T}^{\mathrm{b}}=-0.220\right)$ association between power of making decisions and social exclusion for both Muslims and non-Muslims. Non-Muslims seem to do much better in terms of social inclusion in poor state of decision-making. The result of groups based on religious affiliation indicated that variation in association between social exclusion and power of making decision is explained by religious affiliation as a control variable. It could be concluded that Muslim participants had inclinations of participation in decision making at household level, however, this phenomenon amongst non-Muslims was much obvious. Muslims had maximum opportunities of social participation with other groups based on majority, while non-Muslim had a better level of interaction in most activities of life to their own faith holders, especially at their family level. This situation was found to be a major supporter in the way of their social participation at family level. Poverty, as disclosed by the (Daly and Leonard, 2002; and Sutton et al., 2007) could only be mitigated through maximum participation on part of socially excluded groups. Moreover, freedom of choice in peer group activities like sports in Australia have proven successful in addressing social exclusion amongst the poor and minority children (kid's status, 2007).

For those respondents from joint families who were socially excluded, $98.8 \%$ had weak decision-making abilities, compared to $81.8 \%$ of the socially included. Likewise, for those respondents from nuclear families who were socially excluded, $92.1 \%$ had weak decisionmaking abilities, compared to $79.7 \%$ of the socially included. In addition, for those respondents from single parent families who were socially excluded, $100 \%$ had weak decision-making abilities; with none of the respondents from this category having strong decision-making abilities. A negative relationship $\left(T^{b}=-0.260\right)$ was found between power of making decision in respondents from joint family and their social exclusion (Table 5). The relationship between these variables also was highly significant $(p=0.000)$. Similar to above 
group, in nuclear family this relationship was negative $\left(T^{b}=-0.171\right)$ and significant $(p=0.008)$. The relationship of social exclusion and decision-making power of children from single parent families was a constant. The values of level of significance of the entire table show a highly significant $(p=0.000)$ and negative $\left(\mathrm{T}^{\mathrm{b}}=-0.220\right)$ association between power of making decision and social exclusion for all family types. The result of groups based on joint and nuclear family affiliation indicated a non-varying relationship between power of making decision in children and their social exclusion. However, single parent family group had a varying relationship with above two groups based on previously mentioned variables. Therefore, children from single parent family system, with weak decision-making abilities were more likely to be socially excluded than other family types. Weak decision making abilities is a major cause of social exclusion in all family types, however, children from single parent families, due to absence of one parent, had led to the lacuna of social process pertaining to decision making. On the other hand, their children who lacked the social experience of participation along with restrictions in participation due to stigmatized position, as an outcome of family breakup, had high chances of social exclusion. These findings support the inference (Daly and Leonard, 2002; Sutton et al., 2007; Adelman et al., 2003; and White's et al., 2002) that the drastic effects of limited decision-making capacity at the family level could be mitigated by focusing on the four main aspects of social exclusion. These include the right to survival, to development, access to information and the right to participate across the board.

The findings regarding decision making power and social exclusion while controlling sufficiency of family income unveil that for those respondents with insufficient family income who were socially excluded, $96.7 \%$ had weak decision-making abilities, compared to $89 \%$ of the socially included. Likewise, for those respondents with sufficient family income who were socially excluded, 94.1 had weak decision-making abilities, compared to $77.8 \%$ of the socially included. A negative relationship $\left(T^{b}=-0.155\right)$ was found between power of making decision in respondents from families with insufficient income and their social exclusion (Table 5). The relationship between these variables also was significant $(p=0.016)$. Similar to above, the relationship in families with sufficient income was negative $\left(T^{\mathrm{b}}=-0.188\right)$ and significant $(p=0.002)$. The values of level of significance of the entire table show a highly significant $(p=0.000)$ and negative $\left(T^{b}=-0.220\right)$ association between power of making decisions and social exclusion for both income groups. The result of groups based on sufficiency of family income as a control variable indicated that variation in association between power of making decision in children and their social exclusion is not explained by sufficiency of family income. These findings suggest that effect of power of making decision was universal in social inclusion of children irrespective of sufficiency of their family income. This is perhaps the outcome of cultural prerogatives where young are taught to internalize the basic values and norms of the society and at appropriate stage transmitting the authority of decision making, while making them able citizen to contribute. These findings support the assertion by Sutton et al. (2007) that children's' participation in organized social activities and decision making guarantees them to have higher level of social inclusion.

Table 4: Association between power of making decision and social exclusion in children (controlling gender of the respondents)

\begin{tabular}{|c|c|c|c|c|c|}
\hline \multirow{2}{*}{$\begin{array}{l}\text { Gender, } \\
\text { religion, } \\
\text { family type } \\
\text { and family } \\
\text { income }\end{array}$} & \multirow{2}{*}{$\begin{array}{l}\text { Power of } \\
\text { making decision }\end{array}$} & \multicolumn{3}{|c|}{ Social Exclusion } & \multirow{2}{*}{$\begin{array}{l}\text { Statistics } \\
\chi^{2} \\
(\mathrm{P}-\text {-Value }) \\
\mathrm{T}^{\mathrm{b}}\end{array}$} \\
\hline & & $\begin{array}{l}\text { Socially } \\
\text { Included }\end{array}$ & $\begin{array}{l}\text { Socially } \\
\text { Excluded }\end{array}$ & Total & \\
\hline \multirow[t]{3}{*}{ Male } & Weak abilities & $200(80)$ & $153(95.6)$ & $353(86.1)$ & \multirow{3}{*}{$\begin{array}{l}\chi^{2}=19.89 \\
(0.000) \\
T^{b}=-0.220\end{array}$} \\
\hline & Strong abilities & $50(20)$ & $7(4.4)$ & $57(13.9)$ & \\
\hline & Total & $250(100)$ & $160(100)$ & $410(100)$ & \\
\hline Female & Weak abilities & 28 (93.3) & $58(96.7)$ & $86(95.6)$ & $\chi^{2}=0.523$ \\
\hline
\end{tabular}




\begin{tabular}{|c|c|c|c|c|c|}
\hline & Strong abilities & $2(6.7)$ & $2(3.3)$ & $4(4.4)$ & \multirow{2}{*}{$\begin{array}{l}(0.469) \\
\mathrm{T}^{\mathrm{b}}=-0.076\end{array}$} \\
\hline & Total & $30(100)$ & $60(100)$ & $90(100)$ & \\
\hline \multirow[t]{3}{*}{ Muslim } & Weak abilities & $213(84.9)$ & $208(97.3)$ & $421(90.5)$ & \multirow{3}{*}{$\begin{array}{l}\chi^{2}=20.51 \\
(0.000) \\
\mathrm{T}^{\mathrm{b}}=-0.210\end{array}$} \\
\hline & Strong abilities & 38 (15.1) & $6(2.8)$ & $44(9.5)$ & \\
\hline & Total & $251(100)$ & $214(100)$ & $465(100)$ & \\
\hline \multirow{3}{*}{$\begin{array}{l}\text { Non- } \\
\text { Muslim }\end{array}$} & Weak abilities & $15(51.7)$ & $3(50)$ & $18(51.4)$ & \multirow{3}{*}{$\begin{array}{l}\chi^{2}=0.006 \\
(0.939) \\
\mathrm{T}^{\mathrm{b}}=0.013\end{array}$} \\
\hline & Strong abilities & $14(48.3)$ & $3(50)$ & $17(48.6)$ & \\
\hline & Total & $29(100)$ & $6(100)$ & $35(100)$ & \\
\hline \multirow[t]{3}{*}{ Joint } & Weak abilities & $108(81.8)$ & $84(98.8)$ & $192(88.5)$ & \multirow{3}{*}{$\begin{array}{l}\chi^{2}=14.66 \\
(0.000) \\
\mathrm{T}^{\mathrm{b}}=-0.260\end{array}$} \\
\hline & Strong abilities & 24 (18.2) & $1(1.2)$ & 25 (11.5) & \\
\hline & Total & $132(100)$ & 85 (100) & $217(100)$ & \\
\hline \multirow[t]{3}{*}{ Nuclear } & Weak abilities & $110(79.7)$ & $93(92.1)$ & 203 (84.9) & \multirow{3}{*}{$\begin{array}{l}\chi^{2}=6.97 \\
(0.008) \\
T^{b}=-0.171\end{array}$} \\
\hline & Strong abilities & $28(20.3)$ & $8(7.9)$ & $36(15.1)$ & \\
\hline & Total & $138(100)$ & $101(100)$ & $239(100)$ & \\
\hline \multirow{3}{*}{$\begin{array}{l}\text { Single } \\
\text { Parent }\end{array}$} & Weak abilities & $10(100)$ & 34 (100) & $44(100)$ & \multirow{3}{*}{$\begin{array}{l}\chi^{2}= \\
\text { constant } \\
(0 .) \\
\mathrm{T}^{\mathrm{b}}=0 .\end{array}$} \\
\hline & Strong abilities & $0(0)$ & $0(0)$ & (0) & \\
\hline & Total & 10 (100) & $34(100)$ & $44(100)$ & \\
\hline \multirow{3}{*}{$\begin{array}{l}\text { Insufficient } \\
\text { family } \\
\text { income }\end{array}$} & Weak abilities & $81(89)$ & $147(96.7)$ & $228(93.8)$ & \multirow{3}{*}{$\begin{array}{l}\chi^{2}=5.82 \\
(0.016) \\
\mathrm{T}^{\mathrm{b}}=-0.155\end{array}$} \\
\hline & Strong abilities & $10(11)$ & $5(3.3)$ & $15(6.2)$ & \\
\hline & Total & $91(100)$ & $152(100)$ & $243(100)$ & \\
\hline \multirow{3}{*}{$\begin{array}{l}\text { Sufficient } \\
\text { family } \\
\text { income }\end{array}$} & Weak abilities & $147(77.8)$ & 64 (94.1) & $211(82.1)$ & \multirow{3}{*}{$\begin{array}{l}\chi^{2}=9.086 \\
(0.002) \\
T^{b}=-0.188\end{array}$} \\
\hline & Strong abilities & $42(22.2)$ & $4(5.9)$ & 46 (17.9) & \\
\hline & Total & $189(100)$ & $68(100)$ & $257(100)$ & \\
\hline
\end{tabular}

Values in table present frequency while values in parenthesis represent percentage proportion of respondents

\section{Interaction of power of making decision, gender, religion, family type and sufficiency of family income in social exclusion of children}

Exclusionary effects of interaction of study variables are reflected in figure-1 and 2 . The result made it evident that Muslim female children class with poor power of making decision was most vulnerable to social exclusion on the scale devised for this study (figure 1 bottom right). Conversely, there was a visible drop in social exclusion among male Muslim children irrespective of their capacity to make decisions (figure 1 top right). Exclusionary effects of power of making decision were not variable among non-Muslim children of both genders (figure 1 top and bottom left).

Exclusionary effects of interaction of power of making decision, family type and sufficiency of family income is given in Figure-2. Children with insufficient family income, regardless of family type and capacity to making decision, were more liable to social exclusion than children having family income sufficient for their needs. Fahmy et al. (2009) also listed similar associates of multiple disadvantages including situation of employment, educational accomplishment, tenancy of accommodation, family type, matrimonial standing, age set and sex. Low educational attainment and unemployment were particularly influential in deep exclusion. The patterns of association of these variables with social exclusion are complex and may vary with life stages and social standings. The study suggested that solitary, separated and widowed persons and their dependents were more prone to disadvantage. Whereas, children, women, low skilled, rental tenants, uneducated and retired people are more exposed to ill effects of deprivations. Despite of serious efforts the incidents of exclusion could not be controlled to desired level and remained persistent over time. 
Figure-1 Interaction of power making decisions, gender and religious affiliation in social exclusion of children

religion

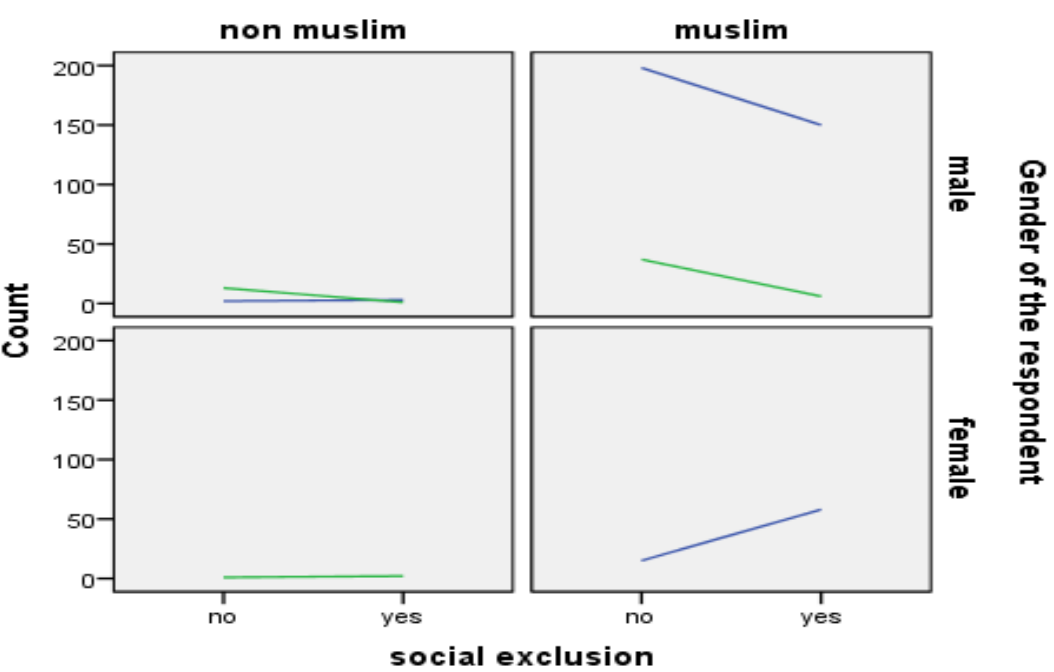

power of making
decision

weak decision making

good decision making

abilities

Result based on primary data collected from 500 children

Figure-1 Interaction of power making decisions, sufficiency of family income and family type in social exclusion of children

Is monthly family income sufficient for family needs?
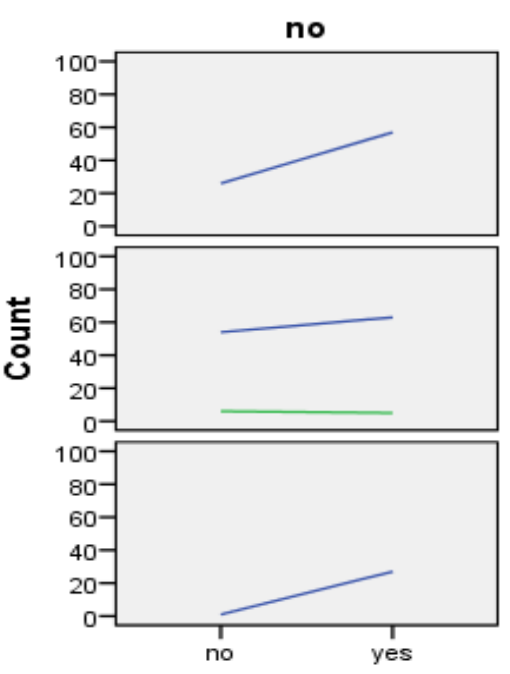

social exclusion
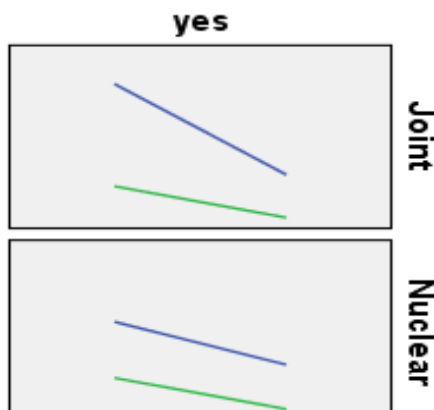

공 冚

을.

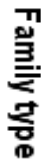

power of making decision

weak decision making abilities

good decision making abilities

Result based on primary data collected from 500 children

\section{Conclusions}

The main objective of this research study was to probe the exclusionary effects of poor decision-making power on children, with relative degrees of variation in effects amongst children of different genders, religion, family type, and family income. The study showed that 
a highly cultural and religious norm was prevalent in the study area which restricted children from participation and discussion at community level decision making process, leading to an obvious social exclusion in children. The division of respondents on the basis of gender, while indexing both independent and dependent variables indicated the social exclusion in children was negative in relation to power of making decision. The results of this study suggest that this domain was conspicuous in its exclusionary effects based on gender and religious affiliation and non-conspicuous on the basis of family type and sufficiency of family income. Therefore, it is concluded that deprivations among children due to participation in decision-making processes had a determining influence on social exclusion among children, especially in female and non-Muslim children.

A welfare state that is focused on employment across all income segments is required to support the constructive social participation of children at both family and community levels. Moreover, a greater focus on the reintegration of family roles in child's physical, social and psychological care and their socialization is required, as is a commitment to overcoming gender and religion based disparities in society. 


\section{References}

Ashworth, K., Middleton, S., Walker, R., Kellard, K., Peaker, A. and Thomas, M. (1994a). Keeping up appearances: peer pressures and children's clothes, in S. Middleton, K. Ashworth and R. Walker (eds.) Family fortunes: Pressures on parents and children in the 1990s, London: Child Poverty Action Group, pp. 51-9.

Ashworth, K., Middleton, S., Walker, R., Kellard, K., Peaker, A. and Thomas, M. (1994b). There's nothing to do 'round here: things children do, in S. Middleton, K. Ashworth and R. Walker (eds) Family fortunes: Pressures on parents and children in the 1990s, London: Child Poverty Action Group, pp. 34-50.

Attree, P. (2004). Growing up in disadvantage: A systematic review of the qualitative evidence. Child: Care, Health and Development, 30 (6), 679-689.

Australian Government. (2009). Transforming Australia's higher education system. Retrieved on 15 October 2012, from

http://www.deewr.gov.au/HigherEducation/Documents/PDF/Additional\%20Report\%2 0-\%20Transforming\%20Aus\%20Higher\%20ED_webaw.pdf

Babie, E. (1989). The Practice of Social Research, Belmont, California, Wades worth Publishing Company.

Backett-Milburn, K., Cunningham-Burley, S. and Davis, J. (2003). Contrasting lives, contrasting views? Understandings of health inequalities from children in different social circumstances. Social Science and Medicine, 57, 613-623.

Baily, K. D. (1982). Methods of Social Research. $2^{\text {nd }}$ Ed. New York. Macmillan Publishing Co., Inc.

Barnes, M., Blom, A., Cox, K., Lessof, C. and Walker, A. (2006). The social exclusion of older people: Evidence from the first wave of the English Longitudinal Study of Ageing (ELSA), Final report, London: SEU/OPDM, January.

Berti, R. (2003). Pistoia: A city that values children, Education Pistoia: edizione junior (pp. 46). Pistoia: Comune di Pistoia. Children, Young People and Social Inclusion: Mobilising to Address Disadvantage on the NSW North Coast: a Literature Review Wilks Wilson ARACY Literature review 12 May 2010.

Better Regulation Task Force. (2004). The regulation of child employment, London: Cabinet Office.

BISE Peshawar. (2011). Gazette book SSC examination. Board of intermediate and secondary education Peshawar. Government of Khyber Pakhtunkhwa.

Bradshaw, J., Kemp, P., Baldwin, S. and Rowe, A. (2004). The drivers of social exclusion: A review of the literature for the Social Exclusion Unit in the Breaking the Cycle series, London: SEU/ODPM.

Burchardt, T., Le Grand, J. and Piachaud, D. (2002). Degrees of exclusion: developing a dynamic multidimensional measure, in J. Hills, J. Le Grand and D. Piachaud (eds) Understanding social exclusion, Oxford: Oxford University Press, pp. 30-43.

Bureau of statistics. 1998. Demographic indicators. Pakistan Bureau of Statistics. Government of Pakistan. Retrieved on 20 October 2012, from http://www.pbs.gov.pk/content/demographic-indicators-1998-census.

Castillejo, C. (2012). Exclusion: A hidden driver of Pakistan's fragility. NOREF Policy Brief. Norwegian Peace Building Resource Centre.

Christensen, P. and James, A. (2000). Childhood, diversity and commonality: some methodological insights. In P. Christensen and A. James (Eds.), Research with children (pp. 160-179). London: Palmer Press.

Commins, P. (2004). Poverty and social exclusion in rural areas: Characteristics, processes and research issues. Sociologia Ruralis, 44, 60-75.

Convention on the Rights of the Child. (1989). United Nations High Commissioner for human rights: United Nations Human Rights. Retrieved on $20^{\text {th }}$ April 2012, from http://www.ohchr.org/EN/Professionallnterest/Pages/CRC.aspx.

Cooper, D. R. and Pamela. S. S. (2010). Business Research Methods. Islamabad. National 
Book Foundation.

DSS (Department of Social Security). (1999). Opportunity for All: Tackling poverty and social exclusion, Cm 4445, London: The Stationery Office.

Fahmy, E., Ruth, L., David, G. and Demi, P. (2009). Understanding the risks of social exclusion across the life course: Working age adults without dependent children. A Research Report for the Social Exclusion Task Force, Cabinet Office. University of Bristol.

Feeny, T. and Boyden, J. (2004). Acting in Adversity - Rethinking the Causes, Experiences and Effects of Child Poverty in Contemporary Literature. QEH Working Paper Series: Working Paper No. 116. Oxford University Press: Oxford, UK.

Hoffmann-Ekstein, J., Michaux, A., Bessell, S., Mason, J., Watson, E. and Fox, M. (2008). Children's agency in communities: A review of the literature and the policy and practice context The Benevolent Society, ANU, Social Justice Social Change Research Centre University of Western Sydney, NAPCAN.

Kid's status. (2007). Child participation in socio-economic activities. Retrieved on $25^{\text {th }}$ December 2012, from http://www.kids.nsw.gov.au/kids/kidsstats/community/childparticipation/figuresocioec onomicstatus.cfm .

Levitas, R., Christina, P., Eldin, F., David, G., Eva, L. and Demi, P. (2007). The multidimensional analysis of social exclusion. Bristol institute of Public Affairs, Bristol.

Marsh, A., Gordon, D., Pantazis, C. and Heslop, P. (1999). Home Sweet Home? The impact of poor housing on health, Bristol: The Policy Press.

Nachmias. C. F. and David Nachmias. (1992). Research Methods in Social Sciences. $4^{\text {th }}$ Ed. St Martin's Press Inco. New York. USA.

Roker, D. (1998). Worth more than this: Young people growing up in family poverty, London: The Children's Society.

Saunders, P. (2007). Towards New Indicators of Disadvantage Project: Bulletin No. 2: Deprivation in Australia. Social Policy Research Centre Newsletter No. 96, May 2007: 7-10.

Sekaran, U. (2003). Research Methods for Business. USA, Hermitage Publishing Services. SEU (Social Exclusion Unit). (1997). Social Exclusion Unit: Purpose, work priorities and working methods, London: SEU.

SEU. (2006). A Sure Start to later life: Ending inequalities for older people, London: ODPM. Shropshire, J. and Middleton, S. (1999). Small expectations: Learning to be poor. Joseph Rowntree Foundation: York, UK.

Silver, H. (1998). Policies to Reinforce Social Cohesion in Europe, In Social Exclusion: An ILO Perspective, 38-73. Geneva: ILO.

SPARC. (2011). The state of Pakistan's children. Retrieved on $24^{\text {th }}$ October 2012, from www.sparcpk.org.

Sutton, L., Smith, N., Dearden, C. and Middleton, S. (2007). A child's-eye view of social difference. Joseph Rowntree Foundation: York, UK.

Tai, S. W. (1978). Social Science Statistics, it Elements and Applications. California, Goodyear Publishing Company.

UNICEF. (2011). UNICEF and ILO call for end to hazardous and exploitative child labor on world day against child labor. Retrieved on $17^{\text {th }}$ January 2013 , from http://www.unicef.org/pakistan/media_7071.htm .

Walker, A., and Walker, C. (1997). Britain Divided: The Growth of Social Exclusion in the 1980s and 1990s. Child Poverty Action Group.

White, H., Levy, J. and Masters, A. (2002). Comparative Perspectives on Child Poverty: A Review of Poverty Measures. Save the Children UK: London. 


\section{Biographical Notes}

Dr. Asad Ullah is working as Assistant Professor in the Department of Rural Sociology, The University of Agriculture, Peshawar. He completed his PhD in Rural Sociology with main focus on child's social exclusion and inclusion related issues. Dr Ullah has thirty two research publications with the main focus on social inequality, quality of life, and health.

Dr. Mussawar Shah is a Professor and Chairman in the Department of Rural Sociology, The University of Agriculture, Peshawar. He is an expert in population studies with specific focus of contraceptive use behaviour. Dr Shah has seventy research publications in his academic account. 